\title{
RUDJER BOŠKOVIĆ INSTITUTE RADIOCARBON MEASUREMENTS II
}

\section{DUŠAN SRDOČ, ADELA SLIEPC̆EVIC*, JOSIP PLANINIC***, BOGOMIL OBELIC; and BRANKO BREYER}

\author{
Institute "Rudjer Bošković", P.O.B. 1016, Zagreb, Yugoslavia
}

The present list contains dates of samples measured since our previous list (R., 1971, v. 13, p. 135-140). As before, age calculations are based on the Libby half-life $5568 \pm 30 \mathrm{yr}$, and reported in years before 1950. The modern standard is 0.950 of the activity of NBS oxalic acid, giving a net counting rate of $21.68 \mathrm{cpm}$. The background count is measured by a series of inactive samples such as marble, anthracite, petroleum coke, and old natural methane. Background count of these samples give a mean value of $6.05 \mathrm{cpm}$. It is observed that marble always gives the highest value of background count while natural methane gives the lowest. Results, however, are within $\pm 1 \sigma$ of the mean value.

The reduction of nearly $3 \mathrm{cpm}$ in background count with respect to previous values listed in R., 1971 , v. 13, p. $135-140$ is obtained by adding a $10 \mathrm{~cm}$ layer of low background lead (Mežice, Yugoslavia) around the guard counter and by increasing the gas pressure in the guard counter from 0.9 to $2 \mathrm{~atm}$. Also, an electronic shield consisting of a steel cabinet containing the counters, the preamplifiers, and the lead shield eliminated background variations caused by electric noise.

Before combustion, wood and charcoal were treated with $4 \% \mathrm{HCl}$ and $4 \% \mathrm{NaOH}$. The counting method is essentially the same as clescribed in R., 1971 , v. 13, p. 135-140, using a 1.1L proportional counter at 3atm $\mathrm{CH}_{4}$ pressure. Sample descriptions were prepared in collaboration with collectors and submitters. The errors quoted correspond to $l_{\sigma}$ variation of sample net counting rate and do not inclucle the uncertainty in $\mathrm{C}^{14}$ half-life. Data are not corrected for isotopic fractionation. The recent activity of speleothems (dripstones) is assumed to be $85 \%$ of modern samples; therefore 1305 yr has been subtracted from the radiocarbon age (Münnich and Vogel, 1959).

\section{ACKNOWLEDGMENTS}

We thank the Council of Scientific Research of SR Croatia for providing partial financial support. We also thank E. Hernaus for preparation of samples and methane synthesis, B. Novak for data processing, and $V$. Andreic and A. Gregoran for construction and maintenance of gas lines and electronics.

\footnotetext{
* Faculty of Veterinary Medicine, Univ, of Zagreb, Yugoslavia.

** Faculty of Pharmacy and Biochemistry, Univ. of Zagreb, Yugoslavia.
} 


\section{SAMPLE DESCRIPTIONS \\ ARCHAEOLOGIC SAMPLES}

\section{A. Yugoslavia}

\section{Z-164. Kupa near Karlovac}

$$
281 \pm 67
$$

Fragment of wooden boat from muddy bed of Kupa R. ncar Karlovac $\left(44^{\circ} 50^{\prime} \mathrm{N}\right.$ Lat, $15^{\circ} 23^{\prime} \mathrm{E}$ Long), Croatia. Coll. 1970 and subm. by S. Janjic, Mus. Karlovac.

\section{Z-204. Osor}

\section{A.D. 1855}

$$
95 \pm 79
$$

Fragment of beam from sea near Osor, Cres I., Adriatic Sea ( $44^{\circ}$ $40^{\prime} \mathrm{N}$ Lat, $14^{\circ} 20^{\prime} \mathrm{E}$ Long). Coll. 1971 and subm. by V. Uranija, Mus. Zadar.

\section{Z-221. Punta sv. Ivana}

Wood from sand, $25 \mathrm{~m}$ deep in sea, probably part of wooden ship, $\mathrm{W}^{\top}$ of Viganj on Pelješac Peninsula $\left(42^{\circ} 59^{\prime} \mathrm{N}\right.$ Lat, $17^{\circ} 6^{\prime} \mathrm{E}$ Long), SE Croatia. Coll. 1971 and subm. by ž. Rapanić, Archaeol. Mus., Split.

\section{Z-223. Bribir}

$1021 \pm 65$

Wood from coffin containing human skeleton, found in Bribir near Skradin (43 $56^{\prime} \mathrm{N}$ Lat, $15^{\circ} 51^{\prime} \mathrm{E}$ Long), S Croatia. Coll. 1972 and subm. by S. Gunjača, Inst. Natl. Archaeol., Split.

\section{Z-224. Vučedol}

$237 \pm 63$

\section{A.D. 1713}

Fragment of wooden boat (Quercus) from muddy bed of Danube R. $3 \mathrm{~km}$ downstream from Vukovar $\left(45^{\circ} 20^{\prime} \mathrm{N}\right.$ Lat, $19^{\circ} 00^{\prime} \mathrm{E}$ Long), NW Croatia. Coll. 1972 and subm. by H. Malinar, Croatian Inst. Restoration, Zagreb.

\section{Z-217. Prozor}

$$
2386 \pm 58
$$

Fragment of charred wooden board covering grave No. 44 at $80 \mathrm{~cm}$ depth near Otočac (44 $50^{\prime} \mathrm{N}$ Lat, $15^{\circ} 10^{\prime} \mathrm{E}$ Long), Lika, Croatia. Site was settlement of Japods, an Illyrian tribe. Buckle ornamented with amber found in same grave indicates late Iron period. Coll. 1971 and subm. by R. Dreksler, Archaeol. Mus., Zagreb.

\section{Bezdanjača series}

Wood and speleothems from Bezdanjača cave, Brakusova Draga near Vrhovine $\left(44^{\circ} 50^{\prime} \times\right.$ Lat, $15^{\circ} 23^{\prime} \mathrm{E}$ Long), Lika, Croatia. Cave is $1 \mathrm{~km}$ long and 42 to $300 \mathrm{~m}$ deep. Served as necropolis to Protojapodes. Wood subm. by R. Dreksler and H. Malinar and speleothem by M. Malez, Yugoslav Acad. Sci., Zagreb. Ceramics indicate middle Bronze age (1500 to 1300 B.c.), or late Bronze age (1300 to 1200 B.c.). Some wooden samples 
are sticks of circular or semicircular sec. (branchlets) ca. $20 \mathrm{~cm}$ long found around fireplaces and probably served as torches; others are more or less flat, dressed sticks ca. $20 \mathrm{~cm}$ long with sharpened and partly burned tips, found close to skeletons and probably served in funeral rites. Analysis of wooden sticks made by B. Petrić and V. Šcukanec, Fac. Forestry, Univ. Zagreb.

\section{Z-174. Bezdanjača 1}

$3351 \pm 77$ entrance.

\section{Z-186/I. Bezdanjača 2}

$2986 \pm 75$

Decosect 1036 B.c. Decayed short sticks (Corylus spp. Betulaceae, Fraxinus spp. Oleaceae) from Grave 21, Block 24. Comment: date suggests contamination with recent organic matter.

\section{Z-186/II. Bezdanjača 3}

$3299 \pm 61$

Ceremonial torches (Pinus sylvestris), Grave 21, Block 24.

\section{Z-191/I. Bezdanjača 4}

$2229 \pm 75$ 279 B.C.

Stalagmite core deposited on pottery in Grave 21, Block 24 at same place as Z-186/1I.

\section{Z-191/II. Bezdanjača 5}

Outside liyer of stalagmite deposited on pottery.

\section{Z-219. Bezdanjača 6}

Partly burned wooden sticks, Grave 19, Block 23.

\section{Z-220. Bezdanjača 7}

Wooden construction ncar fireplace, Block 1.
$1275 \pm 70$

A.D. 675

$3060 \pm 58$ 1110 B.C.

$2867 \pm 75$ 917 B.C.

\section{St. Donat series}

Wooden beams (Quercus) from gallery floor in St. Donat church, Zadar, SE Croatia $\left(44^{\circ} 5^{\prime} \mathrm{N}\right.$ Lat, $15^{\circ} 15^{\prime} \mathrm{E}$ Long). Only well-preserved beams with 110 to 120 tree rings which could be easily counted were drilled out, each containing 10 to 20 tree rings as indicated below. Samples subm. 1970 by Ksenija Radulić, Inst. Preservation Cultural Monuments, Zadar. B. Bersa and C. Iveković think St. Donat church was erected in 6th century, V. de Ponte and $\mathrm{K}$. Bulic believe in the 9th century (Petricioli, 1962).

\section{Z-177. St. Donat}

Tree rings 0 to 20 .

$$
1389 \pm 60
$$


Tree rings 0 to 10 .

\section{Z-178/I. St. Donat}

$1302 \pm 67$

Tree rings 90 to 100 .

General Comment: based on mean value estimated by weighted means of the 3 samples, trees were in cut A.D. $695 \pm 55$. It was assumed that $30 \pm 10$ tree rings of sapwood were cut away during shaping of beams. This would be earliest date that beams could be used for construction of gallery floor. However, the possibility exists that wood was stored for some years or that it was used in another building and built into St. Donat church afterwards.

\section{Stobi series}

Charcoal (except at noted) from Stobi, at junction of Cinat R. with Vardar R., S of Titov Veles, Macedonia, $\left(41^{\circ} 33^{\prime} \mathrm{N}\right.$ Latt, $21^{\circ} 59^{\prime} \mathrm{E}$ Long). Site dates from late Roman times and earlier. lexcept where noted, samples were coll. by hand and put in polyethylene bags for storage. Coll. 1971 and subm. by J. R. Wiseman and E. M. Davis, Stobi Excavations, Naroden Muzej, Titov Veles, Yugoslavia, and Classics Dept., Univ. Texas, Austin. Many of these samples are also being dated by Univ. Texas lab. Dates will be discussed elsewhere, (Wiseman and Mano-Zissi, in press).

\section{Z-207. Stobi R-71-3}

$1611 \pm 69$

Episcopal basilica, $S$ stairway, $W$ extension; above Steps 2, 3, 4 of $\mathrm{S}$ stairway, alt. 146.89 to $147.39 \mathrm{~m}$. Later than final destruction of building.

\section{Z-216. Stobi R-71-14A}

$1779 \pm 66$

$\mathrm{W}$ cemetery, $\mathrm{S}$ trench, $\mathrm{N}$ and $\mathrm{E}$ parts; from zone resting on Wall 8 , alt. 148.97 to $149.22 \mathrm{~m}$, with abundant pottery of 1 st and 2nd centuries A.D. Stored damp in polyethylene bag for 3 weeks, then dried.

\section{Z-213. Stobi R-71-15}

$1836 \pm 68$

Nuts; W cemetery, $S$ trench, from fill in E end of Grave 21, assoc. with bulbous unguentarium, probably 1 st century A.D. Wrapped in tissue, placed in polyethylene bag: tissue removed 3 weeks later.

$$
1769 \pm 69
$$

\section{Z-212. Stobi R-71-33}

A.D. 153

House of the Fuller; charred beam in destruction layer on highest of 4 floors, final destruction of building; alt. 149.25 to $149.66 \mathrm{~m}$. Ceramics late 4 th century. Coll. by hand into tray, moist; transferred to polyethylene bag, left open for 6 weeks in basement lab. 
Z-210. Stobi R-71-34

$1883 \pm 72$

IV cemetery, fill of Grave 82, from early history of ccmetery.

\section{Z-206. Stobi R-71-35}

$1877 \pm 65$ or earlier.

W cemetery, fill of Grave 57, early in history of cemetery, A.D. 150

\section{Z-215. Stobi R-71-36}

$1619 \pm 65$

Acropolis, Trcnch 1, from destruction debris in Room 4; probably a roof beam. Should date end of last occupation in this part of site. Ceramics and coins indicate 5 th or possibly 6th century A.D.

\section{Z-205. Stobi R-71-37}

$1619 \pm 66$

Episcopal basilica, S stairway, $\mathrm{NE}$ area of E Ext. 5; from Wall \#5 to and beyond Wall \#13. Burned timber from final layer of destruction fill in this area above latest carth floor; alt. 143.37 to $143.98 \mathrm{~m}$.

Z-211. Stobi R-71-38

$1759 \pm 61$

Episcopal basilica, baptistry; from deposit above NE and NW parts of mosatic floor encircling piscina. Alt. 143.15 to $143.39 \mathrm{~m}$.

\section{B. Paleolithic and Mesolithic of Central and Eastern Europe}

\section{Z-188. Strmica}

$33,540 \pm 1830$

31,190 в.c.

Bone collagen from Strmica $\left(44^{\circ} 10^{\prime} \mathrm{N}\right.$ Lat, $16^{\circ} 20^{\prime} \mathrm{E}$ Long), $12 \mathrm{~km}$ $\mathrm{N}$ of Knin, SE Croatia, in valley of Butišnica R. Coll. 1971 and subm. M. Malez, Yugoslav Acad. Sci., Zagreb.

\section{Z-189. Velika Pećina Cave, Layer $g$}

$27,300 \pm 1200$

Charcoal from hearth in Layer $g$ from Velika Pećina Cave near Veliki Goranec $\left(46^{\circ} 17^{\prime} 10^{\prime \prime} \mathrm{N}\right.$ Lat, $16^{\circ} 02^{\prime} 22^{\prime \prime}$ E Long) near Ravna Gora, NW Croatia. Layer contains bones and teeth of Pleistocene animals and flint and bone artifacts of Aurignacian industry. Coll. 1970 and subm. by M. Malez. Comment (M.M.): results agree well with earlier analysis of layers $c$ (GrN-4980) and $c$ (GrN-4990) (Malez and Vogel,
$1970)$.

\section{Z-190. Mali Bukovac}

$$
257 \pm 59
$$

Soil with charcoal pieces in Layer $a$ from Mali Bukovac rock shelter on Sleme near Lokve (45 $21^{\prime} \mathrm{N}$ Lat, $12^{\circ} 25^{\prime} \mathrm{E}$ Long), Gorski Kotar, W Croatia. Layer contains bones of recent animals. Coll. 1970 and subm. by M. Malez. Comment (M.M.): date as expected. 


\section{Z-193. Šandalja}

Charcoal grains mixed with clay in Layer $\mathrm{c} / \mathrm{d}$ from cave in Šandalja limestone quarry, (44 $52^{\prime} 57^{\prime \prime} \mathrm{N}$ Lat, $13^{\circ} 53^{\prime} 48^{\prime \prime} \mathrm{E}$ Long), $4 \mathrm{~km} \mathrm{E}$ of Pula, Istra, W Croatia. Layer contains teeth and bones of Plcistocene animals and flint artifacts attributed to Gravettian culture. Coll. 1970 and subm. by M. Malez. Comment: dates agree well with results of Layer $b$ GrN-4978: 12,320 \pm 100 , and Layer e GrN-5013: 29,450 \pm 180 (R., 1972, v. 14, p. 66), of same site.

\section{Z-195. Podosojna Cave}

$2833 \pm 72$

Charcoal grains mixed with soil from Layer $d$ in Podosojna Cave SE of Detani village near Mošćenička Draga $\left(45^{\circ} 15^{\prime} \mathrm{N}\right.$ Lat, $14^{\circ} 14^{\prime}$ E Long) Istra, W Croatia. Layer contains prehistoric ceramics. Coll. 1970 by J. Radovčić, Yugoslav Acad. Science, Zagreb, subm. by M. Malez. Comment (M.M.): expected age $\sim 4000 \mathrm{yr}$.

\section{Z-196. Medvjedja pećina}

$25,745 \pm 670$ 23,795 в.c.

Fragment of spcleothem; part of Layer $b$ from Bukovac cave on Sleme near Lokve (45 $20^{\prime} 30^{\prime \prime} \mathrm{N}$ Lat, $12^{\circ} 25^{\prime} 17^{\prime \prime}$ E Long) Gorski Kotar. Coll. 1971 and subm. by M. Malez. Comment (M.M.): date as expected.

\section{Z-198. Podosojna}

$6470 \pm 95$

Charcoal grains mixed with soil uncler Layer $f(\mathrm{~g})$ in Podosojna Cave SE of village Detani near Moščenička Draga $\left(45^{\circ} 15^{\prime} \mathrm{N}\right.$ Lat, $14^{\circ}$ $14^{\prime} \mathrm{E}$ Long) Istra. Layer contains prehistoric ceramics. Coll. 1970 and subm. by J. Radovčić.

\section{Veternica series}

Veternica Cave is $700 \mathrm{~m} \mathrm{~N}$ of Gornji Stenjevec near Zagreb $\left(45^{\circ}\right.$ $50^{\prime} 36^{\prime \prime} \mathrm{N}$ Lat, $13^{\circ} 32^{\prime} 24^{\prime \prime} \mathrm{E}$ Long), NW Croatia. Four samples are from 2 vertical profiles of compact speleothem forming Layer $c$. Distance between profiles is ca. $8 \mathrm{~m}$. Sample Z-194 is from top, and Z-201 from bottom of lst profile of speleothem, $70 \mathrm{~cm}$ thick here, and forms uppermost layer in this region of cave. Sample Z-218/II is from top, Z-218/I from bottom of 2nd profile of the same speleothem, which is here only $10 \mathrm{~cm}$ thick and covered with $40 \mathrm{~cm}$ thick Layers $a$ and $b$. Coll. 1971 and subm. by M. Malez.

\section{Z-194. Veternica 1}

$4655 \pm 90$

Fragment of speleothem (Layer $c$, top). Comment (M.M.): expected age: 3000 to 5000 B.c.

\section{Z-201. Veternica 2}

$12,355 \pm 180$

Fragment of speleothem (Layer $c$, bottom). 


\section{Z-218/I. Veternica 3}

$11,095 \pm 150$

Fragment of speleothem (Layer $c$, bottom).

9145 B.C.

\section{Z-218/II. Veternica 4}

$\mathbf{4 4 9 5} \pm \mathbf{8 0}$

Fragment of speleothem (Layer $c$, top).

\section{B.C.}

\section{REFFRENGES}

Malcz, M. and Vogel, J. C., 1970, Die Ergebnisse der Radiocarbonanalysen der Quartären Schichten der Velika Pecina in Nordwest Kroatien: Sci. Sec. A, Bull., v. 15, p. $390-391$.

Mümich, K. O. and Vogel, J. C., 1959, Alterbestimmung von Süsswasser-Kalkablagerungen: Naturwissenschaften, v. 46 , p. 168 .

Petricioli, I., 1962, Donat, Sv.: Enciklopedija likovnih umjetnosti, v. 2, p. 73-75, Izdanje Leksikografskog zavoda FNRJ, Tagreb, 1962.

Srdoc, 1)., Breyer, B., and Sliepcevic, A., 1971, Rudjer Boškovic Institute radiocarbon measurements I: Radiocarbon, v. 19, p. 135-140.

Vogel, J. C. and Waterbolk, H. T., 1972, Groningen radiocarbon dates X: Radiocarbon, v. 14, p. 6-110.

Wiscman, J. and Mano-Zissi, Dj., (eds.), Studies in the antiquities of Stobi: v. 1, in press. 